\title{
PRESIDENTIAL ELECTION METHODS AND URBAN-ETHNIC INTERESTS
}

\author{
Allan P. SindleR*
}

This paper attempts to evaluate American presidential election methods by criteria including, but extending well beyond, the commonly used ones of vote equality, reduction in the distortion of the popular vote, and minimization of the chances of electing a minority President. The conclusion reached is that retention of the current procedure is preferable to any of the major suggested reforms that has some chance of being adopted as a constitutional amendment. In support of that conclusion, a justification for inflated urban influence is offered and some perspectives for the understanding of ethnic politics are suggested. ${ }^{1}$

\section{Evaluating Presidenttal Election Methods}

The importance of the Presidency to the character and operation of the over-all governmental and party system needs no belaboring. The mode of presidential election constitutes one of the important determinants of the nature of the office. It therefore follows, and the point merits emphasis because too many popular criticisms of the electoral college have overlooked it, that any analysis of the current method or of proposed reforms must take very much into account the broader consequences of the election procedure for the political system. In pursuing such an approach, we shall probably find wider agreement on what the probable effects of one or another election device are than on any ultimate evaluation of the relative worth of the respective alternatives. The latter disagreement derives basically from the variety of important criteria relevant to the problem, and from the fact that different observers attach different weight to each criterion.

Debate over presidential election methods is refreshing in that much of it may proceed from a contemporary rather than from an eighteenth-century perspective. By this we mean simply that because the electoral college device has never operated in the manner intended by the Framers, considerably, less attention may be given

- A.B. I948, A.M. I950, Ph.D. r953, Harvard University. Associate Professor of Political Science, Duke University. Author, Huey Long's Louisiana: State Politics, 1920-1952 (1956), The Unsolid South: A Challenge to the Democratic Party, in A. F. Westin (ED.), THE Uses OF Power (1962). Contributor to political science periodicals.

2The popular conception of "minority group" is equivalent to the meaning of the term "ethnic" as here used. Accordingly, more is meant than a group in which the members possess a distinctive sociocultural tradition based on nationality origin, religion or race, and which, relative to the total population, is numerically in the minority. Of the many groups that would qualify under those standards, we mean to include as "ethnies" primarily those whose deviation from one or more of the three clements of the "majority" pattern-Anglo-Saxon, Protestant, white-has resulted in social imposition on the group of subordinate status and significant patterns of discrimination. 
on this problem, compared to many others, to the question of the intent of the Framers. The thoroughness and rapidity with which the operation of the electoral college was altered should be a familiar enough story to permit treatment of it here in summary terms.

The functioning of the electoral college method, as originally envisioned, depended too much on the absence of political factionalism. When partisanship made its clear and enduring appearance-and the evidences of it were apparent throughout President Washington's administrations-fundamental changes in the actual operation of the electoral college necessarily followed, even though most of the form remained intact. The electors abandoned, in effect, the discretionary powers granted to them by the Constitution and became the controlled spokesmen for the authority designating them, whether that was the state legislature or the electorate. In a matter of several decades, because the states were coerced into adopting a uniform stateunit (or general ticket) system by the dynamics of that device, there remained little significance to the exclusive power granted each state to determine for itself the manner in which it would distribute its electoral vote. The expectations inferable from the arrangements for contingent House selection of the President, involving state equality, also proved illusory within a relatively short time. Aided generally by the structuring force of partisanship, and particularly by the arithmetical consequences of the state-unit ("winner take all") system, the actions of the electoral college itself regularly produced Presidents instead of merely supplying the top contenders from whose ranks the House would designate the victor. A similar turnabout occurred when the neatness of the Framers' plan in regard to the VicePresidency-to award that post to the losing major presidential candidate rather than to contest directly for it-was rudely shattered by the partisan-inspired necessity for electors to distinguish sharply between candidates for the two different offices. This deviation from intent led to formal alteration of the Constitution by means of the twelfth amendment in I804. Finally, the broad politicization of the electoral college procedure modified its indirect character, though it still remained and remains importantly different from direct popular election.

It is no exaggeration to conclude that the electoral college as we know it is a gross perversion of the intent of the Framers. As a consequence, critics of the current procedure have not been placed in the pygmies-versus-giants position of attempting to do battle with the American design as set forth by the Philadelphia Convention. And defenders of the current system likewise cannot still criticism by riding the coattails of those who fashioned the Constitution, but must address themselves, notwithstanding their considerable advantage of being on the side of the status quo, to the substance of the argumentation. Since societal values militate against any frontal assault on the artistry of the Framers, the net effect has been to enlarge the range of criteria which may realistically be considered in appraising presidential election methods.

The comparison of electoral vote distributions to popular vote distributions has 
inspired the most persistent criticism of the current method. The criteria implicit in such charges will be discussed shortly. At this juncture, attention may be called to a simplistic variant of this indictment, one that argues that the electoral college should be scrapped merely because it does not translate popular into electoral votes with any arithmetical fidelity. Such critics, difficult as it is to believe, overlook the fact that there would be no point in placing the intermediate mechanism of electoral votes between the voters and the candidates if it served only to reflect with mathematical accuracy the distribution of popular votes. All indirect methods of election must distort the popular vote in some degree. Unless one is wedded to support of direct popular election, a primary reliance on the charge that the electoral college faultily records the popular vote reveals far more about the knowledgeability of the indicter than about the operation of the election system. Since an inaccurate rendering of the popular vote is an inherent characteristic of indirect election methods, the appropriate inquiry becomes not whether such distortion exists, but rather its magnitude and direction. It may be suggested, by way of criteria, that the distortion should not be of such a nature as to heighten the possibility that the election itself will fail to produce a winner or will produce as the winner one who has a lesser amount of popular votes.

A number of other interrelated criteria may be set forth under the general heading of effects on national and state party systems and on voter motivation and influence. The election procedure should contribute to the maintenance of a national two-party system, to increasing the number of two-party states, and to sustaining vigorous inter-party competition at both levels. It should also provide a setting conducive to enlarging voter turnout and to high popular receptivity to the stimulus function of a campaign. A relative equality of, individual voter influence might be urged as a suitable goal, understanding that an indirect election scheme precludes literal equality on the matter. (The question of whether, in judging equality of voter influence, the focus should be extended beyond the presidential electorate to include national and state legislative electorates plays a most important part, as will be seen, in the ultimate evaluation presented in this paper.)

The impact of election method on two of the organizing principles of American government necessitates the introduction of additional criteria. The way in which a President is chosen should be supportive of the separation of powers, with particular reference to maintaining the independent and different electoral bases of President and Congress. With regard to federalism, it is better not to assert a fixed position but to raise the question of the extent to which the states should be treated as the basic structuring units of the presidential election.

One final standard, applicable to reform proposals only, requires mention. Adoption of most suggested revisions of the current procedure, for reasons of practicability or law, would have to be in the form of a constitutional amendment. The standard of political feasibility thus suggests itself, meaning the probability that a specific 
reform would be able to secure the requisite approval of two-thirds of the Congress and three-quarters of the states.

Consideration of these criteria, some of which are competing rather than complementary, leads to the conclusion that no one election method can satisfy them equally. Hence, as urged earlier, each observer must rest his final judgment on some ranking of these goals in order of importance. The more explicit the statement of preferred goals, the more focused the debate can be and the greater the likelihood that the critical points of disagreement can be identified.

\section{II}

\section{The Current Electoral College Procedure}

Broadly, the distortion of the national popular vote distribution by the electoral college scheme results from the fact that the winning candidate's victory rests not on the former base, but on a synthesis of fifty separate and final state choices between competing candidates. More specifically, each of three distinct features of the current method gives rise to significant distortion of the popular vote. One hundred of the total of 537 electoral votes (eighteen per cent) are allocated to the states on the non-population principle of equal state representation, i.e., two electoral votes to each state to match its senatorial allotment. Secondly, each state casts its assigned quota of electoral votes without reference to the turnout proportion of its citizens at that election. These two aspects of the current procedure, which are a part of the original constitutional design, lead to distortion in the direction of giving greater electoral weight per vote cast to voters in the thinly-populated and low-turnout states. The third feature contributory to distortion is one not embodied, even in intent, in the original scheme, namely, the state-unit procedure by which the totality of a state's electoral votes is cast for the candidate with a plurality of popular votes. The effects of this bias are, as will be seen, quite different from those set in motion by the two other aspects just cited.

Once an indirect election procedure distorts, as it must, the popular vote, the possibility exists that the verdict of the popular vote may be overturned. In our day of intense commitment to vox populi, it is obviously insufficient to rejoin that the Framers planned it that way. To facilitate a direct examination of that possibility, inspection of the data on presidential elections from $1872-\mathrm{rg} 60$ in table one should be of use.

It will be seen that the polarization of the total vote between the two candidates is much greater in the electoral vote than in the popular vote. Of the total of forty-six candidate races covered, thirty-eight of them fell within a forty-sixty per cent division of the total popular vote, but only thirteen of them fell within a fortysixty per cent division of the total electoral vote. Note further that on all but one of the thirteen times a candidate secured less than forty-five per cent of the popular vote he got less than forty per cent of the electoral vote; and in all of the eight elections in which a candidate gained more than fifty-five per cent of the popular vote, 
TABLE I

Relationship of Popular Vote Proportion to Electoral Vote Proportion, Democratic and Republican Presidential Candidates, I872-rg6o

\begin{tabular}{|c|c|c|c|c|c|c|c|}
\hline \multirow{3}{*}{$\begin{array}{l}\text { Proportion of Total } \\
\text { Popular Vote }\end{array}$} & \multicolumn{6}{|c|}{ Proportion of Total Electoral Vote } & \multirow{3}{*}{ Total } \\
\hline & \multicolumn{3}{|c|}{ Losers } & \multicolumn{3}{|c|}{ Winners } & \\
\hline & $\begin{array}{l}39.9 \% \\
\text { or less }\end{array}$ & $\begin{array}{l}40.1- \\
44.9 \%\end{array}$ & $\begin{array}{l}45.0- \\
49.9 \%\end{array}$ & $\begin{array}{c}50.0- \\
54.9 \%\end{array}$ & $\begin{array}{l}55.0 \\
59.9 \%\end{array}$ & $\begin{array}{c}60 \% \text { or } \\
\text { more }\end{array}$ & \\
\hline $\begin{array}{l}39.9 \% \text { or less } \ldots \ldots \ldots \ldots \\
40.1-44.9 \% \ldots \ldots \ldots \ldots \ldots \\
45.0-49.9 \% \ldots \ldots \ldots \ldots \ldots \\
50.0-54.9 \% \ldots \ldots \ldots \ldots \ldots \\
55.0-59.9 \% \ldots \ldots \ldots \ldots \ldots \\
60 \% \text { or more } \ldots \ldots \ldots \ldots \ldots\end{array}$ & $\begin{array}{r}6 \\
6 \\
5 \\
\\
\\
\end{array}$ & $\begin{array}{l}\overline{3} \\
\overline{-}\end{array}$ & $\begin{array}{l}\frac{-}{2} \\
\frac{1}{-}\end{array}$ & $\begin{array}{l}\bar{z} \\
\bar{z}\end{array}$ & $\frac{\bar{z}}{\overline{4}}$ & $\begin{array}{l}\overline{1} \\
1 \\
6 \\
6 \\
2\end{array}$ & $\begin{array}{r}6 \\
7 \\
18 \\
7 \\
6 \\
2\end{array}$ \\
\hline Total............... & 17 & 3 & 3 & 3 & 4 & 16 & 46 \\
\hline
\end{tabular}

he won more than sixty per cent of the electoral vote. At least at the extremes, then, the direction of exaggeration by the electoral vote is consistent with the direction of the popular vote. If it be granted that it is beneficial to the nation for an incoming President to have the appearance of greater support than that which he actually obtained, then the tendency of the electoral college procedure to exaggerate the magnitude of the winner's victory can be viewed as an advantage of the present system.

Table one also suggests that the problem of "minority Presidents" relates to situations of a close division of the popular vote when both candidates approach but neither achieves a majority of the popular vote. Of the seven instances of a candidate garnering from fifty to 54.9 per cent of the popular vote, in only one-the disputed election of 1876 - did he fail to secure a majority of the electoral vote. In sharp contrast, the electoral vote proportions of candidates having forty-five to 49.9 per cent of the popular vote are distributed across the board, almost equally divided between losers (ro) and winners (8). In the latter category, then, judging from the data, the possibility of electoral vote repudiation of the popular verdict appears greatest.

That possibility has not become an actuality with any frequency in American political history, the only clear-cut instance being that of 1888 . In that election, Cleveland led Harrison by about 100,000 votes (48.7 to 47.8 per cent of the total popular vote), but secured only $4 \mathrm{I} .9$ per cent of the electoral vote. It may be argued, of course, that even a single such occurrence constitutes damaging evidence against the current method. It must be stressed in response, however, that any indirect election scheme could as easily produce a minority President when the popular vote balance between the candidates is as close as that of 1888 - or as that

\footnotetext{
a The term "minority President," as here used, refers not to the rather frequent instance of the winner having only a plurality and not a majority of the popular vote, but to the case of the winner having less popular votes than the loser.
} 
of I960. Judged by this more realistic standard, the record of performance of the electoral college device gives little comfort to those who advocate its replacement by some other form of indirect election.

On the clearly positive side, the electoral college's distortion of the popular vote contributes mightily, in conjunction with other factors, to freezing out serious (power-seeking) third parties in national politics. (Some refinements of this point will be offered in a later section.) The requirement of an absolute majority of electoral votes, without provision for a runoff election, tends away from multipartyism, while the state-unit system tends to produce the requisite electoral vote majority for one or the other of the major parties. The strong support given by the current device to the maintenance of a national two-party system satisfies a criterion of critical importance to many, including the writer.

The biases of the present method that sustain two-partyism also so condition the conduct of presidential campaigns and, through that means, so shape the larger governmental and party system as to directly involve all the remaining criteria noted earlier. The presidential election strategy imposed on the major parties recognizes and acts on the inequality of voter influence stemming from the operation of the state-unit procedure. The political rule of thumb that emerges may be simply put as follows: states safe for either party merit relatively less attention from both parties; attention must be concentrated on those states in which the election outcome is uncertain and, within that category, on those states in which large blocs of electoral votes are at stake. The latter group, that of key unsafe states, includes most of the populous, urbanized, ethnicized and industrialized states in the nation. Voters and interests in those states, therefore, are able to wield political influence disproportionate to their numbers, especially if the groups involved maintain self-consciousness and high cohesion, e.g., certain ethnic and labor groups.

The pressures generated by the current election procedure thus provide at least a partial explanation for such diverse conditions as the declining influence of the Democratic South within the national Democratic Party, the increasing attention paid by both parties to the aspirations of the Negro, the Republican tendency to choose a presidential nominee markedly more "liberal" than the policy outlook characteristic of that party's congressional wing, and the overrecruitment of twentiethcentury presidential candidates from the states of New York and Ohio. And many of the policy differences between President and Congress, regardless of party labels, may be traced in good part to the more-urban constituency and outlook of the former and the more-rural electorates and attitudes of the latter.

In summary, it has been shown that the electoral college procedure satisfies important values relating to the national two-party system, the separation of powers, the federalistic base of presidential elections, and the self-enforcing character of an indirect election method. The possibility of the election of a minority President, on the basis of the historical evidence, appears stronger in theory than in practice. On the other hand, the current system contributes to a marked inequality of voter power, 
one that varies by state residence. Although the formal rules yield advantages to the sparsely-populated and small-turnout states, the main discrimination works out in favor of states with opposite characteristics. It follows that incentives to increased turnout and strengthened party competition in the many states lacking an effective two-party system are depressed. The broader effects of this bias for the conduct of government and the content of public policy have been suggested. On the understanding that we shall subsequently offer judgment on this pro-urban bias, the analysis of the current method may appropriately be concluded at this point.

\section{III}

\section{Narrowing the Range of Reforms to Be Anazyzed}

In keeping with our focus on the broad political consequences of presidential election methods, we need give only passing mention to several of the less farreaching facets of the current method which might profitably be reformed. In the light of the contradictions between the changed function of the elector and his retention of full discretion as to how to cast his vote, the office of the elector (not the electoral system as such) could well be abolished. Revision of the contingent presidential selection procedures also should be undertaken, the appropriate direction of reform being the inclusion of the population principle to dilute the present exclusive recognition of the federative principle. Finally, there is some merit to the view that since all states operate by the state-unit method, its use should be made mandatory by amendment of the Constitution. It is conceivable, in a manner analogous to the position of the elector, that a state legislature might succumb to the temptation to exercise its granted authority to distribute its electoral votes by some other formula designed to promote partisan, power, or policy goals.

Extensive commentary on several other reforms which clearly have broad-ranging consequences is inadvisable because they fail to pass the test of political feasibility. Any and all of the proposals to adopt direct national popular election of the President or a close approximation of it fall squarely in this category. Such a frontal assault on federalism would be certain to generate more than enough opposition to preclude its passage as a constitutional amendment. Notwithstanding the pro-urban bias of the current method, the small states still retain a relative vote strength greater than they would under popular election, and since urban-ethnic-labor interests would continue to loom large under a direct election scheme, small-state opposition alone would prevent adoption of the measure.

By so delimiting the range of reforms, we emerge with two proposals for consideration, each of which retains the indirect electoral scheme as we have it, but seeks to replace the state-unit aspect of it. We shall analyze these two reforms with an eye to determining whether either remedies defects of the current method without sacrificing the latter's advantages and without creating new disadvantages of an equally or more serious nature. 


\section{IV}

\section{Proportionate Division of the Electoral Vote}

The core of this reform is to substitute for the state-unit allocation of all electoral votes to one candidate a system of proportionate division of the electoral vote by which each presidential candidate will get the same proportion of the state's electoral vote as he does of the state's popular vote. The present formula for determining the number of electoral votes to be assigned to each state remains unchanged. The proportion of the total electoral vote required for, victory has been set, in various versions of the proposal, at a plurality, forty per cent, or fifty per cent. (Although some of the effects of the proposal differ depending on which figure is adopted, the present analysis will not turn on that problem.) Over the years the major legislative sponsors of the measure have been Representative Ed Gossett (D., Texas) and Senators Henry Cabot Lodge (R., Mass.), Estes Kefauver (D., Tenn.) and Price Daniel (D., Texas).

The advantages of this scheme over the current method may be readily gauged. By making the electoral vote reflect, rather than suppress, the intrastate division of the popular vote, the proposal would sharply reduce, though not eliminate, inequality of voter power. The distortion of the popular vote based on the electoral weight assigned each state and on the irrelevance of turnout rates would remain, though the impact of the latter would be minimized because of the incentives inherent in the proposal to enlarged turnout in all states. Since a vote gained anywhere would become an increment of electoral vote strength, the major parties would move away from disproportionate attention to the populous states and would campaign broadly and vigorously in every state. On a national basis, the electoral vote proportions of the major-party candidates would tend to come within a few percentage points of their popular vote proportions. Under conditions of a close division of the popular vote, then, a minority President would still be possible. If the popular vote balance were not close, however, in theory the proportionate method would be considerably less likely to produce a minority President than the current system. (Recall, however, that the latter eventuality has not as yet occurred under those conditions.)

However, the probable impact of the reform on the maintenance of the national two-party system is adverse, and that criterion is of sufficient importance to the writer to require the judgment that the reform, on balance, should be rejected. To substantiate the position that the goal of sustaining the two-party system is poorly served by the proportionate plan, three quite different lines of argument must be examined, only one of which provides solid supporting evidence for the view here taken.

The weakest of the three arguments, although one commonly used, merits only brief attention, namely, that the proportionate division of the electoral votes itself is analogous to, and will lead to, a system of proportional representation for congressional elections. The adoption of the latter procedure, in turn, would encourage 
the development of multi-partyism in national politics. Although one could defend the proposition that proportional representation need not necessarily lead to multipartyism, the argument can be disposed of on prior grounds. Simply put, proportional representation cannot be operative in the election of a single person; the term is without application to the problem of presidential election methods here under study. Hence, at least to those who pay attention to the meaning of words and to the actual operation of institutional arrangements, the proportionate plan involves nothing that would lend support to advocacy of proportional representation for the election of national legislators.

A second line of argument also urges that the proportionate plan would promote multi-partyism, not in the form of advancing a theory of proportional representation that might then be applied to the Congress, but in terms of direct encouragement to third parties to contest in presidential politics. A related effect of such a proliferation of third parties would be the reduced probability that one of the major-party candidates could secure the requisite proportion of electoral votes. To the degree that the reform did spawn presidential third parties, then the self-enforcing character desired of a presidential election method would be impaired.

At first blush, this argument carries conviction since, unlike the present method, the reform does award electoral votes to all candidates in accordance with their popular vote strength, no matter how slim, in each state. Does it not then follow that, lured by the "guarantee" of electoral votes, third parties will increase in number? This suggested sequence of cause and effect is, as will be shown, overly simple-it does not "then follow," and it may not follow at all. It would be helpful to the structure of the analysis to distinguish initially among types of third parties before proceeding to grapple directly with the problem posed.

Ideologically-oriented third parties outside the mainstream of national power politics, such as Vegetarians, Socialist Workers, Single Taxers, etc., may appropriately be excluded from consideration here. Their continuing participation in presidential politics derives from motives other than a pursuit of power, and hence alterations of the power aspects of the election procedure should serve neither to encourage or discourage their nominal presence in the presidential arena. The analysis focuses entirely, then, on third parties, such as those of economic protest or of "blackmail" factional defection, which do seek to influence the outcome of particular elections and to alter the policy course of one or both of the major parties. These poweroriented parties may draw their voter support either in concentrated fashion from a region, wherein they may have great strength, or in diffused fashion across the nation, wherein they are likely to have slim minority strength. The data set out in table two provides a base for discussing the probable impact of the proportionate plan on each of these two types of serious third parties. ${ }^{3}$

\footnotetext{
${ }^{3}$ The writer does not share the view, apparently held by many commentators on presidential election methods, that recalculating past elections by the formulas proposed in the various reforms yields evidence of high relevance and value. The assumption implicit in such a view is that "other things are equal," an assumption singularly out of place in the light of the far-ranging consequences for campaign strategy and
} 
TABLE II

Third-Party Vote, Actual and Hypothetical, i948 Presidential Election

\begin{tabular}{|c|c|c|}
\hline 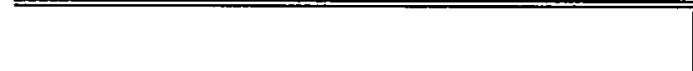 & Stateg' Rights Partix & ProgregstVe PARTY \\
\hline 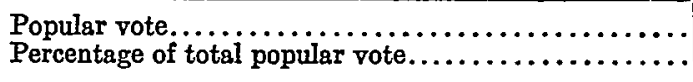 & $\begin{array}{l}1,176,154 \\
2.4 \%\end{array}$ & $\begin{array}{l}1,157,236 \\
2.4 \%\end{array}$ \\
\hline 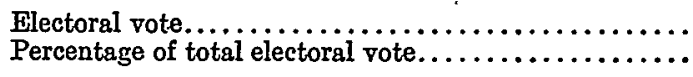 & $\frac{38}{7.2 \%}$ & $\begin{array}{r}0 \\
0 \%\end{array}$ \\
\hline $\begin{array}{l}\text { Electoral vote, proportionate plan .................. } \\
\text { Percentage of total electoral vote, proportionate plan... }\end{array}$ & $\begin{array}{l}38.6 \\
7.3 \%\end{array}$ & $\begin{array}{l}9.4 \\
1.8 \%\end{array}$ \\
\hline
\end{tabular}

It will be noted that the electoral vote translation of the nearly identical number of popular votes won by both third parties differs greatly, both in the actual election and under the hypothetical conditions of the proportionate plan. The variation occurring under the current method occasions no surprise, because the States' Rights Party drew virtually all its following from a number of southern states while the Progressives had broader support throughout the nation, but not near plurality proportions in any state. In view, however, of the claim that the proportionate plan achieves a close approximation of the popular vote distributions, the relevant data (38.6 to 9.4 electoral votes) are both surprising and instructive. The differences in turnout proportions and population size of the States' Rights-voting states and the Progressive-voting states provides most of the reason why the former's electoral weight per vote cast was much greater than the latter's. The stimulus to increased turnout under the proportionate proposal doubtless would result in reducing the contrast. Nonetheless, the example serves to remind that the proportionate plan retains the sources of bias of the present system other than the state-unit aspect, and that those other biases may continue, even under the reform procedure, to contribute to important distortion of the popular vote.

It would not be accurate to infer from the data in table two that a sectionallybased third party, in the manner of the States' Righters, would be expected to garner about the same number of electoral votes under either election method. Much would depend on such variable factors as the geographic focus and turnout characteristics of the vote, and on other situational elements as well. The tabular data may fairly be generalized, however, to support the conclusion that a third party whose voters are thinly distributed around the nation, in the manner of the Progressives, will capture significantly more electoral votes under the proportionate plan than under the present system. We thus have returned full circle to the problem as initially set forth.

The beginning point in its solution turns on the realization that the number of electoral votes won by a third party is a most imperfect index of its effect on the for voter alignments that flow from the adoption of one or another election method. The writer, therefore, has relied little on the evidence supplied by such recalculations, and does so in the present instance only as an illustration of the argument, hot as its content. 
election outcome, i.e., of its political influence in the immediate sense. In the 1948 election, the Progressives and the States' Righters each represented a punitive flank attack, from opposite ideological directions, on the Democratic Party. Both failed in their common short-run purpose of bringing about the defeat of Truman. But the Progressives, with no electoral votes, affected the disposition of a considerably larger number of electoral votes than did the States' Righters, who actually secured thirty-eight electoral votes. The size of the Progressive vote exceeded the Republican lead over the Democrats in New York, Michigan, and Maryland causing Truman the loss of seventy-four electoral votes. And had the Progressives taken away a fraction more of the Democratic vote in Ohio (another 7,108 votes) and in California (another I7,866 votes), Truman would have lost an additional fifty electoral votes to Dewey. Indeed, had the latter situation occurred, then, adding in the thirty-eight electoral votes of the States' Righters, Truman would have been denied an electoral majority and the selection of a President would have been assigned to the House of Representatives. ${ }^{4}$

The ability of both the Progressives and the States' Righters to deprive Truman of electoral votes suggests a refinement of the conclusion reached earlier that the current method is supportive of the national two-party system. The modification should be added that the current method can be exploited, and in that sense, invites exploitation, by ad hoc, transitory third-party activity. The States' Righters secured electoral votes by means of a regional protest which temporarily displaced Democratic dominance in four states of the South. The Progressives' influence on the electoral vote distribution far exceeded that to which their popular vote strength entitled them because they were able to capitalize on situations of close major-party balance in states with large blocs of electoral votes.

May it then be concluded that the proportionate plan, in spite of its automatic translation of popular votes into electoral votes, offers less incentive to third parties than the current method does? The answer is in the negative. Under the proportionate plan, assuming certain conditions that could well have occurred, the Progressives' 9.4 electoral votes in 1948 might have been equally crucial to the outcome. Most probably the thirty-eight electoral votes of the States' Righters would have given them far greater influence under the proportionate plan than was the case under the present state-unit scheme.

We conclude that the translation of third-party electoral votes (or lack of electoral votes) into political strength cannot be measured by a simple count of how many electoral votes were won, but instead is a relative concept involving the total context of the size and geographic distribution of major-party and third-party popular votes and the particular kind of election procedure. Compared to the present system, the

- The reader should be alerted, in the manner of the preceding footnote, to the sharp limits on the inferences that may properly be drawn from such manipulations of election data. The election effects of third parties are never uni-directional, e.g., the entry of the Progressives in 1948, by enhancing the antiCommunist image of the Democrats, strengthened the appeal of the Democrats among other groups. Once again, the writer is using the data not as precise arithmetical evidence but only to illustrate the direction of the appropriate inference that can be made. 
proportionate plan would tend to increase third-partyism under one combination of variables, and to discourage third-partyism under another combination of variables. And the frequency with which one or the other combination would likely appear is not open to advance calculation. Hence we judge that there is no solid evidence to support the second line of argument that the appearance of power-seeking third parties would be encouraged by the reform proposal under discussion.

Moreover, if we assume for the moment the validity of the second line of argument, many of the undesirable effects could still be eliminated by refinement of the reform proposal. The possibility that the total of electoral votes gathered by nuisance and serious third parties would deprive either major party of the requisite proportion of the electoral vote could be met by lowering that latter requirement to forty per cent or, if need be, to a plurality. Or, moving in the other direction, the right to share in a state's electoral votes could be limited to, say, the top three presidential candidates in the state. Since either revision would be quite in keeping with the spirit of the proportionate plan, a rejection of the plan because of its alleged stimulation of third-party activity is all the more untenable.

The third and final line of argument also addresses itself to the impact of the reform on national two-partyism, but without reference to fears of multi-partyism at either presidential or congressional levels. Quite the contrary. The assertion is that the proportionate plan, in the light of contemporary political alignments of the voters, would tend to produce a trend to predominant one-partyism in presidential politics, namely, facilitating Democratic control of the White House by means which would reflect and contribute to the heightened influence of the southern faction of the Democratic Party. The fullness of the discussion thus far in this section permits substantiation of this view in summary form.

In recent decades, the eleven southern states of the Confederacy have been allocated a little under one-quarter of the total electoral votes (about 127 of 531). During the four Roosevelt administrations, the South watched its influence decline in the presidential wing of the Democratic Party even as it continued to cast its regional vote solidly for Roosevelt-and the two patterns were much related, for reasons set forth in the earlier analysis of the current method. Even assuming, though, that the South had rebelled and had cast all its electoral votes for his Republican rivals, Roosevelt would nonetheless have won every one of his elections. The stateunit system, in brief, permitted the Democratic Party to free itself from any great dependency on the South because the party could get its electoral majority by slimmer margins of popular strength in many non-southern states. The same pattern, of necessity, would have to underlie Republican presidential victories, at least prior to recent elections.

It seems evident that the South's political influence would be enhanced under the proportionate plan, the extent of the increased influence depending on one's estimate of the two-party division of the electoral vote in the South under conditions encouraging maximum turnout of registered voters. Suppose, for example, that the 
South's electoral vote were to divide seventy-five to fifty-two in favor of the Democrats, giving the latter a net gain of twenty-three electoral votes from the region. Those twenty-three electoral votes could not easily be offset in the rest of the nation, by either the Republicans or the non-southern Democrats, because of the small net electoral vote gain to either party derived from slim margins of popular victory in the urban-industrialized states. A lead of twenty-three electoral votes in the nonSouth would represent a popular vote lead of several millions. If the estimate made is realistic, then the Democratic Party would gain significant competitive advantage for control of the Presidency, an advantage that could be counteracted effectively by the Republicans only if their candidate was able to secure that margin vote lead in the non-South portion of the nation. This important Democratic edge in presidential elections, in turn, would bear the price tag of a considerable dependency on the continued support of its southern wing, a dependency that would inflate southern influence over the content of public policy.

Is the estimate realistic? No demonstration is possible for this estimate, or for any other. To this writer, it does seem more rather than less probable that the South, under the proportionate plan, would contribute an important number of electoral votes to the Democrats. A significant portion of the notable upsurge of presidential Republicanism in the South in recent elections, for example, stems from popular disaffection with the national Democratic Party. ${ }^{5}$ If the southern point of view were to receive more attention within Democratic councils, then presumably most of those protesting voters would happily return to the Democratic fold. Moreover, important as the presidential election method is to the larger political process, it would be rather extreme to suggest that the current method has distorted what otherwise would be a closely-competitive two-partyism into the situation of Democratic dominance as we have known it. Surely the pronounced and durable past attachment of the region to the Democratic Party has roots deeper and more complex than merely the pressures generated by the mode of presidential election. The election method, on the other hand, does appear to be a critical factor in the extent to which the southern commitment to the Democratic Party becomes the determining element in the outcome of presidential elections.

It is conceivable, if northern Democrats found it impossible to accommodate the South while continuing to try to appeal to metropolitan interests, that the Republican Party might become the beneficiary of southern support. Either way it developed, effective two-party competition in presidential politics would be hampered and the South's influence would rise. It should be remembered that the proportionate plan enhances the political influence of "safer" states and decreases that of closely-divided states. States sharing pronounced sectional interests, like those of the South, would be given every incentive to maximize their power by not developing effective two-party presidential politics. In the light of these considerations, the predictions

"For a detailed case study of recent southern disaffection with the Democrats in presidential elections, see the writer's The Unsolid South: A Challenge to the Democratic Party, in A. F. Westin (ED.), TrE USES OF POWER 229-83, esp. 273-8I (I962). 
of advocates of the proportionate plan that the South will achieve durable twopartyism seem to be based more on hope than reason, and the former provides a poor base to justify fundamental alteration of the mode of presidential election.

$\mathrm{V}$

\section{District Division of the Electoral Vote}

In place of the state-unit system, this reform would establish a district-unit system. Congressional districts would serve also as electoral districts, each of which would be assigned one vote, to be cast in favor of the presidential candidate with the highest popular vote in the district. In addition, each state would cast two electoral votes on the basis of the state-unit procedure. The formula for assigning electoral votes to the states remains unchanged. To win, a presidential candidate has to secure an absolute majority of electoral votes. The legislative sponsors of this reform have included Senators Karl Mundt (R., S.D.) and Everett Dirksen (R., Ill.), and Representative Frederic Coudert, Jr. (R., N.Y.)

The strongest argument against adoption of this reform lies in the fact that the exact nature of most of its important consequences depends too much on the particulars of the districting pattern of each state. American states have no developed tradition of equity in the apportionment of seats or in the drawing of district boundary lines for either the state or national legislature. The reform under discussion, by vastly increasing the stakes involved in districting, could not help but persuade the controlling partisans of the necessity to rig the political boundaries in their party's favor. Any "reform" permitting the projection of these inequitable practices directly into the presidential arena should be repudiated out of hand.

It constitutes a less than adequate rejoinder to observe that the reform could impose a uniform requirement on the states to construct districts that were geographically contiguous and approximately equal in population, and could additionally provide for effective enforcement mechanisms. Such a provision would eliminate only some but far from all of the opportunities for partisan gain in the drawing of political lines. Suppose, for example, that areas $A$ and $B$ are each made up of eightyfive Democratic voters, while areas $C$ and $D$ are each made up of seventy-five Republican voters. Two districts are to be established, each to be composed of from 150 to r7o persons. A combination of $A C$ and $B D$, or of $A D$ and $B C$, would yield two Democratic districts; that of $A B$ and $C D$ would yield one Democratic and one Republican district. The political history of the states, in short, provides no grounds for confidence that the requirement of equal-population districts, even if enforced (as might follow from Baker $v$. Carr ${ }^{6}$ ), would serve to confine the ingenuity of lawmakers intent on implementing the goal of party malapportionment.

It follows that the district proposal cannot be subjected to the type of rigorous analysis applied earlier to the current method and the proportionate plan. (In both those methods, the electoral unit is the state, which is a fixed entity not alterable

${ }^{\circ} 369$ U.S. 186 (1962). 
by legislative whim.) The more superficial arithmetical effects of the reform can be gauged, but the political meaning of those effects turns on the districting problems just discussed. For example, party emphasis on pivotal states under the current scheme would likely be supplanted by an equivalent emphasis on pivotal districtsbut the number and characteristics of the latter would be determinable by districting and could be changed by redistricting. The present distortion of major-party popular vote by the electoral vote would be reduced by the district plan-but the possibilities of a minority President again would turn on the particular configuration of districts established for that election.

To say that the district plan defies definitive analysis of its consequences is not to say that some suspicions about the probable directions of its effects are not in order. The bias of the current method is clearly known, and the district proposal would eliminate the main source of that bias, the state-unit system. The legislative sponsors of the reform are conservative in policy complexion. And several of the respective backers of the proportionate plan and the district plan are on record as indicating that, if their plan failed of adoption, they would support the other plan. In its intent, then, the district plan suffers from no ambiguity: its aim is to distribute political influence in a manner quite different from that which obtains under the current system. The exact details of which non-urban interests gain what share of increased influence become quite secondary to that central aim, as indicated by the contingent pledges of mutual support by the backers of the two reform proposals here examined. The identification of common anti-urban motivations underlying these reforms provides an appropriate context for the concluding section of the analysis.

\section{VI}

The Anti-Urban Polittcs of Electoral College Reform

It should be clear, if not on a priori grounds then on the basis of the analysis presented, that presidential election methods are neither neutral nor identical in their consequences for the distribution of political influence. The truth of that observation is insufficiently realized by those civic-minded citizens whose advocacy of the need for electoral college reform derives primarily from a sense of outrage at the arithmetical distortions of the current system and the biases of voter inequality that result. From such an essentially superficial view, either or both the proportionate and district plans appear more preferable to follow. More tough-minded political observers and participants, however, are keenly aware that the replacement of the state-unit system results, not in the elimination of bias, but in the substitution of one kind of bias for another. The broader directions of the consequences of enacting either of the two reform proposals are anti-urban, anti-ethnic, and anti-labor, in the sense of reducing the political influence of those interests. And many of those favoring adoption of a different indirect election scheme than the present method are motivated consciously to realize those ends. 
The determination of the precise beneficiaries in the redistribution of political influence that would occur is not so certain a matter as the identification of the antiurban effects. The analysis here undertaken suggests that, under the proportionate plan, southern political power would increase and most probably would constitute a critical element in the election outcome. Whichever party the South gave disproportionate support to-and it would doubtless be the Democrats in the beginningwould gain a significant enough edge over its rival to depress the chances of maintaining the turnover rate in party control of the Presidency at a level consistent with effective two-partyism. Under the district plan, it is less clear whether rural Republicans or rural Democrats would get the lion's share of the power wrested from metropolitan groups.

Party and factional congressional alignments on the proposals support the analytic themes and inferences here drawn. In I950, when the House defeated the proportionate plan, most of the support for the measure came from southern Democrats. In 1956, the Senate sponsors of the two reform proposals combined forces and offered a constitutional amendment that, among other things, permitted a state to choose between the proportionate plan and the district plan for each election. Although such a hybrid proposal lacked most of whatever merit either reform would have if taken alone, it nearly secured the two-thirds vote needed for passage. For present purposes, we need note only that southern and rural-state senators provided the bulk of the votes for the measure.

Deviation from the alignments indicated requires a word of additional explanation. Some liberal legislators, such as Senators Lodge and Kefauver, believe that the proportionate plan would revitalize southern two-party competition to the extent that both major parties could effectively compete in the region and, therefore, in the nation. Their motivation, as they would doubtless see it, is not anti-urban but proequity. Some Republican conservative legislators supporting one or both reform proposals, on the other hand, may have thought through the policy consequences more carefully than the party consequences. They probably have assumed that whatever reduces the political power of metropolitan areas must also result in a reduction of the power of the Democratic Party. To many in this group, of course, it would not be a very bitter pill to swallow if it turned out that conservative southern Democrats were the prime gainers.

It appears, then, that any indirect election device not closely approximating direct popular election is productive of strong biases favoring some segments of the population and disadvantaging other segments. The question of "reform" in this area, as a consequence, should not be understood as a nonpartisan matter of "fairness versus inequity," but as a profoundly political problem: Whose interests should the necessarily biased procedures favor?

To take a position on that problem in terms other than the rhetoric of partisans, one must move away from a restricted focus on presidential election methods to encompass the larger political system. Whose interests are unduly served by the 
election procedures for the state legislatures, the Senate, the House? Should the Presidency also be brought into the orbit of that exaggerated rural influence? Or should not urban-ethnic-labor influence, by the doctrine of a checks and balances of interests, be granted one important area of countervailing power?

To invoke a standard of offsetting one inequity by another may be disturbing or offensive to some, but a realistic analysis of presidential election methods leaves little choice in the matter. After all, many of those most outspoken on the immorality of the current system are conspicuously silent when it comes to extending their principles to the arena of election methods for state and national legislatures. It should be understood that the basis for judgment here is a contingent one which would call for quite different conclusions if the condition of excessive rural influence were corrected. But not even those who, like the writer, are highly pleased with the Supreme Court's recent decision in Baker v. Carr ${ }^{7}$ would hold that the time to draw those different conclusions had arrived.

\section{VII}

\section{An Epilogue on Ethnic Politics}

The analytical case for retention of the current method has been presented. It rests, negatively, on the inappropriateness of extending further the influence of rural interests already disproportionately represented and, positively, on the pluralistic justice of maximizing urban influence in one important arena of national politics. There are many who might agree with the drift of the argument here presented, but who nonetheless would balk at endorsing a continued magnification of urban political influence. The reluctance to accept the latter condition often stems from doubts concerning the legitimacy of one important component of urban influence, namely, ethnic politics. This epilogue seeks to complement the analytical presentation by developing perspectives on ethnic politics which may resolve the doubts of those otherwise disposed to accept the conclusions reached in this paper.

Representative Ed Gossett (D., Texas), in testifying in I95I in support of the proportionate plan, offered some frank comments on his view of ethnic group influence: ${ }^{8}$

The electoral college permits and invites irresponsible control and domination by small organized minority groups, within the large pivotal states. It aggravates and accentuates the building up and solidification within these states of religious, economic, and racial blocs: Small, definable, minority groups, organized along religious or economic or racial lines, by voting together, can and do hold a balance of power within these pivotal states. As a result, the political strategists in both parties make special appeals to these various groups as such. These groups have become more and more politically conscious. They

'Note 6 supra. The writer's views on the implications of the Baker case for remedying the apportionment problem are set forth in Baker $v$. Carr: How to Sear the Conscience of Legislators, in the forthcoming Fall 1962 issue of the YALE LAW Journal.

${ }^{B}$ Hearings Before Subcommittee No. I of the House Comm. on the Judiciary, Proposing an Amendment to the Constitution of the United States to Abolish the Electoral College System, 82d Cong., Ist Sess. 263 (1951). 
know their power. In many instances, they have no political alignments or philosophy as such, but are simply up for sale to the highest bidder.

For present purposes, we cite Representative Gossett's statement, making due allowance for its tone and for the fact that he was a policy opponent of those groups whose political power he deplored, as broadly representative of the unease and dislike with which many view the existence of ethnic politics.

American cultural values disapprove of a citizen structuring his political attitudes and behavior in terms of a self-definition stressing his nationality, his religion and/or his race. Social disapproval increases if such political behavior assumes the form of a conscious group effort and results in cohesive voting by group members. In sharp contrast, cultural values have something quite different to say about economicbased voting, even of the crassest self-interest type. Why beliefs supportive of "pocketbook" voting and hostile to "ethnic-oriented" voting should have taken hold is too big a question for exploration here. Several strands of thought contributory to the economic-ethnic distinction, however, may be commented on with an eye to encouraging the reader to re-examine for himself the validity of the distinction.?

Some observers, apparently committed to a neo-Marxian view that meaningful political conflict derives primarily from economic tensions, would confine the judgment of "rational" politics essentially to economically-motivated political behavior. Ethnic motivations, together with other traditionalist bases of party attachment, are deplored as an inferior brand of "irrational" politics. We need not become too immersed in the quagmire of probing the meaning of "political rationality" to offer a rejoinder or two. From the viewpoint of the ethnic voter, it would be difficult to sustain the position that his political activity in response to ethnic cues was functionally unrelated to his psychological needs, his social identity, his real interests, or to the content and direction of public policy. And from the viewpoint of the larger community, the maintenance of a low-temperature politics distinguished by little class polarization doubtless owes much to the pervasiveness of orientations to politics other than the economic, such as ethnicity. Indeed, the absence of neat ideological lines in American politics is itself the prime frustration of some of these observers, and leads them to deprecate ethnic-motivated behavior because it cuts across, and therefore complicates, the straightforward political expression of economic interest.

For others, an adverse judgment on ethnic politics stems from a romanticized and inaccurate view of the characteristics of the American mass electorate. The normative picture of the "democratic citizen" is so widely accepted as to lead many to believe that practice matches preachment, that what is corresponds to what is supposed to be. The picture emerges of an informed and alert citizenry, one that combines judicious nonpartisanship with intensity of interest and involvement, that carefully assesses past performance and current pledges of the parties and candidates,

\footnotetext{
- For an account of the party attachment of ethnic groups in American history, a dimension of the topic deliberately not treated in this epilogue, see Lawrence H. Fuchs' contribution to the symposium on Immigration, Some Political Aspects of Immigration, 21 LAW \& CONTEMr. ProB. 270 (1956).
} 
and that has a developed concern for issues. With partisan attachments fluid and the voter's mind open to welcome information on the contemporary policy differences between the parties, election outcomes may properly be interpreted in issue terms of a meaningful mandate from the people to the victors. Measured against such standards, the actual performance of any group cannot help but appear inferior and less commendable.

The inappropriateness of such standards has been amply documented by recent rigorous studies of community and national samples of citizen behavior in presidential elections. ${ }^{10}$ Most adults, the evidence indicates, are psychologically attached to one or the other major party to a degree sufficient to structure their political attitudes and behavior in persistent and predictable ways. Party identification, be it Democratic or Republican, typically is durable; it is constant in direction, becomes more intense over the life cycle of most persons and, through the family and other group forces, is passed down from one generation to another. The sense of attachment to party serves the individual as a perceptual screen to keep the reception of new political stimuli to manageable proportions and, more importantly, to minimize the capacity of external events to alter his party ties. By such selective perception and other mechanisms, party identification becomes self-reinforcing and the voter insulates himself to a considerable degree from tensions produced by conflict between party preference and issue positions. Generally, the level of sensitivity to issues of the mass electorate is low, whether defined in terms of involvement in specific issues or of a patterned structure of attitudes akin to an ideological stance. And the so-called independents, who contribute disproportionately to the ranks of those who change the direction of their vote from one election to the next, are characterized by a pronounced inattention to and uninvolvement in political affairs, not by a closer conformity to the normative standards cited above.

If the foregoing picture of mass voter behavior were able to displace popular misconceptions on the subject, then ethnic politics might be judged more realistically and more sympathetically. To take but one example, consider for a moment the implications of $\mathrm{T}$. $\mathrm{H}$. White's frequent characterization of ethnic groups in his The Making of the President, rg6o, as "tribal communities," about which he deprecatingly asks: "How many Americans are so tied to their past that they cannot be summoned to face the American future?"11 The question may be a fair one, but its pertinency is in no way restricted to ethnic groups. Most persons, including many of those able to offer a variety of "rational" reasons why they intend to vote for this or that candidate, approach an election on the basis of a party commitment of long standing. Typically, that commitment was "inherited" during the period of one's adolescence, a time of relative ignorance of politics, and subsequently reinforced by the mechanisms spoken of earlier. The "cause" of the

${ }^{10}$ See, for example, Angus Campeell et al., The American Voter (I960); the findings therein provide much of the basis for the deseription of the salient characteristics of the mass electorate that follows.

${ }^{11}$ Theodore H. White, The Making of the President, I960, at 227 (I961). 
party attachment, if pushed back far enough, might have been the tariff position of the parties, the Civil War, the help extended to a European immigrant newly arrived in New York City, and the like. Whatever the particular genealogy of a person's current party loyalty, the common feature is the structuring of contemporary attitudes by eras and events long gone. Contrary to White's implication, voters generally, and not just ethnics, react to the present world of politics in terms of a partisan frame supplied by the past.

Another important strand of belief undergirding dislike of ethnic politics relates to popular expectations on the assimilation of immigrant stocks. America as a "melting pot" was understood to mean, as Will Herberg has persuasively argued, a "transmuting pot," i.e., the rapid assimilation of immigrant groups into the larger society on the basis of their willing acceptance of and conformity to Anglo-American values and attitudes. ${ }^{12}$ Some nationality groups, particularly those from southern and eastern Europe, exhibited a slower rate of assimilation than those from western Europe. Retention by those groups of a strong and distinctive ethnic identity was deemed by many as "un-American" in the sense of running afoul of the "transmuting pot" requirements. The assimilation lag was attributed to "defective" qualities in those groups themselves, a viewpoint buttressed by then-current scientific holdings which distinguished among European "races" by their different sociocultural traditions, assigned bio-genetic significance to those traditions, and concluded by judging some immigrant "races" to be innately inferior. ${ }^{13}$ These viewpoints provided the basis for the national-origins concept embodied in restrictive immigration legislation from the I920's to current times. Under these circumstances many Americans, including members of ethnic groups, became acutely sensitive to evidences of persistent ethnic consciousness and collective behavior as implying unwillingness or inability to become integrated in the mainstream of American life.

Although contemporary scientific attitudes on race have fully reversed themselves from the earlier position noted, the belief persists that durable ethnicity suggests an incapacity within the group to become acculturated. We would agree that persistence of ethnic identification indexes a situation of incomplete assimilation, but not that it necessarily provides evidence of the unassimilability of the group. Quite the contrary. The aspirations of ethnic groups make it indisputably clear that they wholeheartedly accept the ideal of the "transmuting pot," and that their goal is to become fully integrated as rapidly as possible in the national community. (The aim of most Negroes, for example, is to be accepted as other Americans are in the nation as it is constituted, not to form a new and exclusivist "nation" in the manner of the Black Muslims or to create a new order in the manner of the Communists.) Accordingly, while the incomplete assimilation of ethnics to date

${ }^{10}$ Will Herberg, Protestant-Catholic-Jew: An Essay in American Reljgious Sociolocy (1960).

${ }^{13}$ For an excellent summary account of the interplay of scientific inquiries and "racist" doctrines, with particular reference to the United States, see Oscar HANdLin, Race and Nationality in Amierican LIFE (1957). 
may be explained in part by reference to group characteristics, the primary reasons relate to the prejudicial attitudes of the larger society to the groups.

The different rates of ethnic group acculturation stem basically, then, not from differences in the degree to which immigrant groups endorse the goal of assimilation, but from variations in social acceptance of the respective groups. Ethnics and non-ethnics are of one mind in viewing a stress on ethnic identity as a stage transitional to the ultimate realization of full Americanization. But ethnics cannot act unilaterally to arrive at that ultimate goal. Full assimilation necessarily involves a social definition no less than the group's self-definition. Ethnics who feel subjected to separatist and discriminatory social treatment quite understandably retain a sense of distinctive identity which guides their outlook and actions in political and nonpolitical matters. The dislike of ethnic politics, therefore, derives in part from the fact that its existence points the finger at a socially-caused gap between theory and practice, at an American dilemma that quite properly troubles the conscience of many citizens. Unfortunately, one all-too-understandable defense mechanism which permits society to cleanse its conscience on the matter is to visit the blame for incomplete assimilation on the ethnic group itself.

Since adverse social attitudes contribute importantly to the maintenance of ethnic identification, the availability to the ethnics of political influence provides them with a means, not merely of self-protection, but of hastening the process of fuller social acceptability and assimilation. The impact of politics on the assimilation process cuts two ways, of course, and many a political pattern has exploited ethnic solidarity in ways calculated to retard progress towards assimilation. But there is considerable insight, for example, in the current strategy that allocates the highest priority, in the struggle for the advancement of the Negro, to the protection of Negro political rights. Politics has constituted a more hospitable channel for the rise of ethnic groups than have most other aspects of American society and, after providing the ethnic groups with "recognition" and with protective power, politics has ultimately forced ethnics to exercise public authority for purposes and interests broader than those of their own group.

On balance, then, the effects of politics on ethnic assimilation have been beneficial both to the group and the society in terms of the criteria laid down by the "transmuting pot" concept. Were ethnic politics to be understood in this context, the strength of the analytical case in support of the pro-urban bias of the present presidential election system could not be discounted because of anxieties concerning the legitimacy of ethnic political influence. 